\title{
Hubert Guz
}

http://orcid.org/0000-0001-8230-6182

Akademia Ignatianum w Krakowie

hubert.guz@ignatianum.edu.pl

\section{Konrad Oświecimski}

http://orcid.org/0000-0002-0873-6827

Akademia Ignatianum w Krakowie

konrad.oswiecimski@ignatianum.edu.pl

DOI: 10.35765/pk.2021.3504.14

\section{Proces opracowania Strategii Rozwoju Województwa Małopolskiego jako przejaw organizacyjnego uczenia się samorządu}

\section{STRESZCZENIE}

Z dzisiejszej perspektywy czasowej województwa samorządowe, w tym Małopolska, to kluczowe podmioty z punktu widzenia rozdysponowywania funduszy unijnych, jak również poważni aktorzy, jeżeli chodzi o realizację wielu zadań z zakresu polityki publicznej i rozwojowej. Wypracowywanie pozycji oraz praktyk związanych z funkcjonowaniem tych podmiotów dokonywało się na początku XXI w., a budowa pozycji tych jednostek, oprócz tego, że obwarowana była ramami instytucjonalnymi, odbywała się również w trakcie i po części na podstawie prowadzonych działań. Jednym z takich kamieni milowych dla samorządowej Małopolski był proces przygotowania przez Urząd Marszałkowski Województwa Małopolskiego (UMWM) pierwszej Strategii Rozwoju Województwa Małopolskiego 2000-2006. Proces ten nie tylko doprowadził do jej stworzenia, ale również ukształtował organizację i przyszłe jej praktyki. Celem niniejszego artykułu jest przeanalizowanie, w świetle teorii organizacji uczącej się Petera Senge'a, w jakim stopniu tworzenie tej Strategii mogło się stać elementem kształtującym organizację - UMWM. Z przyjętej perspektywy autorzy konstatują, że proces tworzenia analizowanej Strategii był istotnym elementem, który miał wpływ na ukształtowanie się organizacji, a tym samym, że organizacje publiczne mogą się uczyć oraz że teorie dotyczące organizacji uczących się znajdują również do nich odniesienie.

SŁOWA KLUCZE: strategia rozwoju regionalnego, uczenie się organizacji, zarządzanie strategiczne, samorząd regionalny, partycypacja 


\section{ABSTRACT}

The Preparation of the Malopolska Region Development Strategy as an Example of Organisational Learning in Self-Government

From today's perspective, local self-government regions, including Małopolska, are key entities as far as the allocation of EU funds is concerned, as well as important actors in the process of implementing many tasks in the field of public and development policy. The development of these local government institutions took place at the beginning of the 21 st century and they formed, apart from being bound by institutional frameworks, in the course of and partly on the basis of their ongoing activities. One such milestone activity for the self-government of Małopolska was the preparation of the first Development Strategy of the Małopolska Region (2000-2006). This process not only led to the creation of the strategy itself, but also shaped the organization (UMWM) and its future practices. The aim of this article is to analyze to what extent the creation of this strategy could have become an element shaping the organization, in the light of Peter Senge's theory of the learning organization. From this perspective, the authors conclude that the process of creating the analyzed strategy was an important element that influenced the formation of the organization and also that public organizations can learn and consequently that the theories of learning organizations also apply to them.

KEYWORDS : strategy of regional development, learning organisation, strategic management, regional self-government, participation

\section{Wstęp}

Województwa samorządowe to dziś kluczowy aktor polityki rozwoju, dysponujący pieniędzmi unijnymi. Do momentu wejścia Polski do UE miały jednak marginalne znaczenie. Pośrednie zaangażowanie w programy przedakcesyjne i pilotażowe działania w ramach Kontraktów Wojewódzkich sprawiło, że regiony zaczęły budować pozycję istotnego podmiotu polityki rozwojowej.

Przełomowy 2004 rok nie przyniósł samorządom województw regionalnych programów operacyjnych (RPO), zostały jedynie zaangażowane do realizacji Zintegrowanego Programu Operacyjnego Rozwoju Regionalnego 2004-2006 (ZPORR), obejmującego jednak 22\% środków europejskiej polityki spójności (Szlachta, 2011). Co więcej, zadania w tym procesie podzielono pomiędzy administrację samorządową i rządową. Powody tego ubezwłasnowolnienia regionów poprzez centralistyczną ustawę o Narodowym Planie Rozwoju są różnie oceniane (Sprawozdanie, 2013). Z jednej strony wskazuje się na naciski brukselskiej administracji, 
która obawiała się braku potencjału w „młodych” samorządach regionalnych. Z drugiej strony, do głosu doszły centralistyczne tendencje w polskiej administracji państwowej (Izdebski i Kulesza, 2004). ZPORR był najszybciej wdrożonym programem operacyjnym w Polsce, a regiony okazały się partnerem wysoko cenionym przez Komisję Europejską (Sprawozdanie, 2013). W kolejnej perspektywie finansowej 2007-2013 samorządy województw stały się Instytucjami Zarządzającymi dla RPO, na które alokowano wtedy 34\% środków unijnych (Szlachta, 2011). W naszej ocenie to rok 2007 stanowił prawdziwy przełom dla samorządów regionalnych jako moment wyposażenia ich w bezpośrednie narzędzie polityki rozwoju - RPO.

Co determinowało sposób działania władz samorządowych i urzędników w momencie rozpoczęcia programowania wsparcia unijnego? W ramach polityki spójności wyraźnie rysują się procesy zarządzania wielopoziomowego oraz cechy specyficzne dla otwartej metody koordynacji (Zawicki, 2010; Grosse, 2012). Oznacza to, że aktorzy polityki spójności działają, w znacznej mierze, autonomicznie. Zewnętrzne uwarunkowania stanowią ramy systemu, pozostawiając pole dla indywidualnego podejścia (NSRO, 2006).

Analizując uwarunkowania wewnętrzne, widać, że Urząd Marszałkowski Województwa Małopolskiego (UMWM) był otwartą, młodą (instytucjonalnie i personalnie) administracją z niewielkim doświadczeniem. Największym wówczas przedsięwzięciem UMWM było przygotowanie pierwszej Strategii Rozwoju Województwa Małopolskiego 20002006 (Strategia). W ocenie autorów oddolna, partycypacyjna i oparta na dialogu metoda pracy nad Strategiq ukształtowała podejście władz samorządowych, urzędników oraz partnerów społecznych, gospodarczych, naukowych do programowania rozwoju i interwencji unijnej.

Celem analizy jest ocena, czy proces budowy Strategii był przykładem uczenia się organizacji. Dodatkowo, autorzy pojęli próbę weryfikacji przydatności teorii uczącej się organizacji do oceny działań instytucji publicznych.

\section{Metoda}

W badaniu zastosowano metodę studium przypadku, który określono jako proces przygotowania Strategii i jego wpływ na podejście do programowania unijnej polityki spójności. W ocenie autorów przypadek jest warty analizy. Po pierwsze, proces przygotowywania dokumentów strategicznych i operacyjnych jest powszechny w administracji. Po drugie, proces ten stanowi laboratorium uczenia się organizacji. Po trzecie, przypadek 
prezentuje zjawisko przenikania się uwarunkowań formalnych i tzw. podejścia do realizacji zadań publicznych. Analiza ma znaczenie praktyczne i daje szansę bezpośredniej generalizacji oraz wykorzystania jej jako dobrej praktyki w samorządach.

Studium ma charakter eksplanacyjno-deskryptywny, jest próbą wskazania związków przyczynowych pomiędzy doświadczeniami z procesu przygotowania Strategii a specyfiką programowania polityki spójności (Ospina, Esteve i Lee, 2017).

Dokonano przekrojowej analizy procesu budowy Strategii. Wykorzystano metodę obserwacji. Jeden $z$ autorów prowadził obserwacje mające znamiona obserwacji uczestniczącej. W okresie 1999-2019 był pracownikiem UMWM, zaangażowanym pośrednio w przygotowywanie poszczególnych strategii rozwoju oraz bezpośrednio - w realizację unijnej polityki spójności. Aby zminimalizować zagrożenia wynikające ze specyfiki studium przypadku, dokonano triangulacji danych, uzupełniając je analizą dokumentów źródłowych oraz wyników badań ewaluacyjnych (Yin, 2015).

Zgromadzone dane umożliwiły wnioskowanie, dokonano generalizacji analitycznej i sformułowano najważniejsze rekomendacje. Autorzy położyli nacisk na możliwość praktycznego wykorzystania ustaleń.

W celu oceny oddziaływania procesu na organizację wykorzystano teorię organizacji uczącej się Petera Senge’a. Autor wskazał kanon elementów procesu uczenia się organizacji obejmujący: myślenie systemowe, mistrzostwo osobiste, modele myślowe, wspólną wizję i zespołowe uczenie się (Senge, 2012). Zweryfikowano, czy elementy te wystąpiły w badanym procesie oraz czy teoria jest adekwatna do oceny działań organizacji publicznej.

\section{Proces budowy Strategii}

Prace nad Strategia prowadzone były od 1999 do 2000 r. Region potrzebował narzędzia zarządzania strategicznego oraz dokumentu uzasadniającego realizację projektów, które miały być docelowo finansowane ze środków europejskich. Czynnik ten ułatwił zaangażowanie się w proces partnerów, którzy mieli świadomość, że priorytety (i projekty) wskazane w Strategii mają szansę na uzyskanie unijnego finansowania.

Strategia to także realizacja wymogów prawa. Ustawa o samorządzie województwa z dnia 5 czerwca 1998 r. określała minimalny zakres celów, precyzowała zawartość dokumentu oraz lakonicznie odnosiła się do procesu tworzenia Strategii, w tym wskazując kluczowych partnerów samorządu (Ustawa, 1998). 
Spełnienie obowiązku ustawowego było proste. Idąc śladem wielu samorządów gminnych, wystarczyłoby zlecić przygotowanie Strategii zewnętrznemu podmiotowi, a wynik tych prac skonsultować ze wskazanymi podmiotami. Władze Małopolski uczyniły jednak z budowy Strategii priorytet, inicjując dialog z szerokim gronem partnerów i wspierając się ekspertami. Strategia stała się także kluczowym przedsięwzięciem UMWM, angażując kadrę zarządzającą i pracowników. Proces oparto na koncepcji zarządzania strategicznego, zakładając m.in. (Górniak i Mazur, 2012; Harmonogram, 1999; Założenia, 1999):

- szerokie uspołecznienie;

- zaangażowanie interesariuszy na każdym etapie prac;

- podejście oddolne;

- długi horyzont czasowy;

- wyznaczenie obszarów działania województwa, hierarchizację problemów;

- uwzględnienie czynników wewnętrznych i zewnętrznych;

- wyznaczenie kierunków rozwoju i priorytetów w ramach obszarów;

- monitoring działań i ocenę efektów.

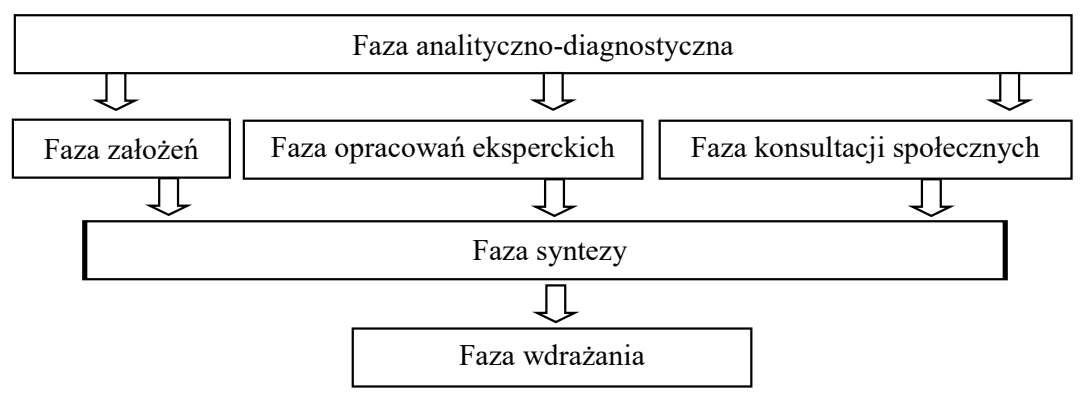

Rysunek. 1. Fazy pracy nad Strategią Rozwoju Województwa Małopolskiego

Źródło: opracowanie własne na podstawie Założenia, 1999; Strategia, 2000.

Proces składał się z sześciu faz:

Faza analityczno-diagnostyczna - w myśl zasad polityki opartej na dowodach opracowano diagnozę stanu - pierwszą odnoszącą się do obszaru nowego województwa (Pawson, 2006). Założono integrację z poziomem lokalnym (m.in. zbadano strategie powiatowe i wyodrębniono wspólne obszary problemowe) (Diagnoza, 2000). Faza „Założeń” - opracowano „Założenia do Strategii Rozwoju Województwa", obejmujące: diagnozę, uwarunkowania, kierunki i scenariusze rozwoju, projekt celów i priorytetów oraz schemat 
dokumentu Strategii. Dokonano oceny ex ante „Założen”” i rozpoczęto konsultacje społeczne (Ewaluacja, 1999; Założenia, 1999; Strategia, 1999).

Faza opracowań eksperckich - w proces zaangażowano środowiska eksperckie: Uniwersytet Jagielloński, Polską Akademię Nauk, Akademię Ekonomiczną, Akademię Rolniczą, Akademię Pedagogiczną, Małopolski Instytut Samorządu Terytorialnego i Administracji. Eksperci przygotowywali analizy sektorowe, konsultowane z zespołem oraz władzami samorządowymi. Opracowano analizę potencjalnych źródeł finansowania Strategii oraz ocenę oddziaływania na środowisko (Prognoza, 1999; Strategia, 2000).

Faza konsultacji s połecznych - partnerzybyli angażowani we wszystkie fazy tworzenia Strategii. Kluczowym mechanizmem były warsztaty problemowe (analiza potrzeby powiatów, wyznaczanie kierunków rozwoju, definiowanie projektów). Zastosowano ankietę „Małopolską Listę Szans” - uczestnicy warsztatów wskazywali priorytety rozwojowe, przeprowadzono ankietę prasową - wpłynęło 2500 ankiet (Małopolska Lista Szans, 2000). Uspołecznienie projektu Strategii odbywało się poprzez spotkania, konferencje, prasę, internet (Strategia, 2000).

Faza syntezy - podsumowano i zagregowano informacje zgromadzone poprzez opracowania sektorowe i analizy eksperckie oraz wyniki konsultacji społecznych. W zakresie struktury celów zastosowano nowatorskie podejście. Zintegrowano cele w pola (mieszkańcy, pejzaż, gospodarstwo, więzi) i powiązane z nimi konteksty (integracja regionalna, międzyregionalna i europejska). Powyższa logika wydaje się bardziej kompleksowa niż stosowane w RPO podejście liniowe. Zdefiniowano osiem celów nadrzędnych, 30 celów strategicznych oraz prawie 80 rozwiązań. Powstał zwarty i komunikatywny dokument (jedynie 100 stron) przyjęty przez Sejmik Województwa Małopolskiego (Strategia, 2000).

Faza wdrażania - zaplanowano wdrażanie Strategii, opracowano prognozę finansową wraz ze źródłami oraz zasady wdrażania i monitorowania. Sporządzono listę wskaźników (syntetycznych i szczegółowych), określając ich stan bazowy. W zakresie instytucjonalnym przewidziano: powołanie komitetu sterującego, pięciu komitetów wdrażających i sekretariatu wdrażania (Strategia, 2000). Powstał Program Wojewódzki - narzędzie wdrażania na okres 2001-2002. Krótszy horyzont czasowy, koncentracja na priorytetowych celach (z 30 wybrano 11) oraz hierarchizacja rozwiązań miały zoperacjonalizować Strategię (Wojewódzki Program, 2000). 
Województwo małopolskie korzystało ze wsparcia eksperckiego (pomoc doradcza konsultantów lokalnych i zagranicznych) w ramach projektu "Wsparcie budowy strategii rozwoju dla nowych województw” finansowanego z programu PHARE INRED. Miało to istotne znaczenie dla podejścia do budowy Strategii. Zapewniono możliwość zaangażowania ekspertów i pozyskania know-how. Ponadto, okres pracy nad Strategiq to czas debaty na temat ustawy o dostępie do informacji publicznej (Ustawa, 2001). Idea transparentności i partycypacji była wyraźnie obecna w dyskursie na temat administracji i samorządu.

Perspektywa czasowa, doświadczenia kolejnych strategii i RPO pozwalają ocenić dziś pierwszą Strategię oraz proces jej przygotowania. O ile logika celów i priorytetów strategicznych - rezultat żmudnego procesu przygotowania Strategii - nie budzi zastrzeżeń, to jej najsłabszą stroną było wdrożenie. Brakowało korelacji pomiędzy strukturą samorządu regionalnego a wyznaczonymi celami. Zmieniły się także uwarunkowania zewnętrzne, procesy decentralizacji zahamowały, nastąpiło opóźnienie wejścia Polski do UE (Raport z realizacji, 2004; Raport z monitoringu, 2003). Zaplanowany, lecz nie wdrożony system monitoringu był zbyt rozbudowany instytucjonalnie - nie przekładał się natomiast na procedury operacyjne. Ambitne założenia o utrzymaniu partycypacyjnego podejścia także na etapie wdrażania Strategii nie zostały zrealizowane (Koncepcja, 2008).

Zaproponowany zestaw wskaźników miał ogólny charakter i zabrakło korelacji z produktami i rezultatami. Województwo od 1999 r. publikuje rocznik o charakterze statystycznym pt. „Raport o stanie województwa”, który zawiera szereg danych społeczno-gospodarczych, jednak struktura raportu nie została zintegrowana ze Strategia ${ }^{1}$ (Raporty, 2000-2006).

Małopolska stosuje budżet zadaniowy, nie udało się wprowadzić korelacji pomiędzy zadaniami budżetowymi a strukturą Strategii ${ }^{2}$. Oznaczało to, że ocena poziomu wydatków na poszczególne priorytety bazowała często jedynie na szacunkach.

We wdrażanie Strategii było zaangażowanych wielu autonomicznych aktorów. O ile proces przygotowania był przewidywalny - województwo inicjowało i koordynowało działania, to w przypadku wdrażania samorząd nie miał efektywnych instrumentów wpływu.

1 Wraz z wejściem Polski do UE stworzono w Małopolsce Obserwatorium Polityki Rozwoju, gromadzące dane i prowadzące badania wspierające procesy zarządzania strategicznego (www. obserwatorium.malopolska.pl).

2 Dopiero po kilku latach wprowadzono do budżetów wieloletnie prognozy finansowe i programy inwestycyjne. 
W związku z aplikowaniem o środki unijne znaczenie Strategii zostało zinstrumentalizowane. Często traktowano strategie (zwłaszcza gminne) jako obowiązkowy załącznik do projektów, uzasadniający ich realizację, a nie jako narzędzie zarządzania strategicznego.

\section{Uczenie się organizacji - ocena}

Dla analizy zasadnicze znaczenie ma ocena sposobu przygotowania Strategii. Procesowe spojrzenie na to przedsięwzięcie to nie tylko informacje o tym, co osiągnięto, ale także wiedza, jak to osiagnięto. Ocena procesu tworzenia Strategii została przeprowadzona na podstawie modelu uczenia się organizacji Senge'a. Intuicyjnie rozumiana teoria Senge'a polega na: zmianie sposobu myślenia (modele myślowe), poznaniu siebie i dzięki temu otwartości na świat (mistrzostwo osobiste), zrozumieniu, jak funkcjonuje organizacja i jej otoczenie (myślenie systemowe), partycypacyjnym budowaniu strategii i celów (wspólna wizja) oraz pracy grupowej przy osiąganiu celów (zespołowe uczenie się) (Senge, 2012).

Weryfikacja, czy uczestnicy procesu, myśląc systemowo, konfrontując swoje modele myślowe, tworzyli wspólną wizję i uczyli się, pozwoli ocenić, czy uczyła się organizacja.

Myślenie systemowe to holistyczne postrzeganie otoczenia i organizacji poprzez wzajemne, dynamiczne powiązania, świadomość wielowymiarowych relacji (przyczyna - skutek - przyczyna), a nie jedynie linearnych (przyczyna - skutek) oraz sprzężeń zwrotnych występujących z opóźnieniem (Senge, 2012). Władze regionalne metodycznie zaplanowały proces - od konceptualizacji do operacjonalizacji. Świadomie zdecydowano się na podejście oddolne, które generuje więcej problemów, zapraszając do współpracy szerokie grono partnerów. Był to wyraz zintegrowanego podejścia, które pozwala dostrzegać relacje pomiędzy zdarzeniami (sprzężenia zwrotne) oraz zachodzące procesy zmian, a nie tylko statyczne obrazy rzeczywistości (złożoność dynamiczna). Z jednej strony, powody partnerskiego, partycypacyjnego podejścia były utylitarne - budowa wizerunku nowej administracji regionalnej. Z drugiej strony, były przejawem myślenia systemowego, które widać nawet w strukturze dokumentu - zdefiniowane pola aktywności oraz integracja celów (rozwiązań, priorytetów) z kontekstami (Strategia, 2000).

Modele myślowe sprzyjające uczeniu się bazują na kulturze otwartości w organizacji, refleksji, stawianiu pytań, dociekaniu i twórczym burzeniu porządku (Senge, 2012). Koncepcja przygotowywania, co kilka lat, strategii rozwoju sama w sobie zakłada celowe pobudzanie twórczego fermentu. Konieczność diagnozowania rzeczywistości, rewizji dotychczasowych 
planów i wyznaczania priorytetów zmusza do refleksji (urzędników, polityków, partnerów i obywateli) ${ }^{3}$. Przyjęta formuła pracy nad Strategiq zakładała otwartość i transparentność oraz poszukiwanie danych i wiedzy, a także szereg konsultacji, ocenę ex ante, analizy sektorowe, które były bezpośrednio konsultowane z zespołem pracującym nad Strategiq oraz władzami samorządowymi (tzw. okrągłe stoły). Pozwoliło to na uzyskanie wartości dodanej poprzez bezpośrednie zaangażowanie partnerów w debatę.

Wspólna wizja rozumiana jest jako wspólnota celu wartego zaangażowania, partnerstwo, wiara w możliwość kształtowania przyszłości, aktywność i praca zespołowa (Senge, 2012). Gdyby nie świadomość ważnego przedsięwzięcia o realnym wpływie na rzeczywistość (unijne pieniądze), zaangażowanie partnerów byłoby trudne. Urzędnicy zrealizowaliby powierzone im zadania, ale twórczy ferment ograniczałby się do ich biurek ze szkodą dla rozwoju regionu.

Przejawem partnerskiego podejścia były konsultacje, które należy nazwać proaktywnymi (Covey, 2020). „Zmuszono” partnerów do aktywności poprzez warsztaty, konferencje, ankiety oraz dyskusje o rozwoju, zoperacjonalizowane przez pomysły na konkretne projekty.

W ramach organizacji - UMWM zaangażowano władze województwa, kadrę zarządzającą, kluczowych pracowników, przedstawicieli podległych jednostek, czyniąc ze Strategii priorytet, wyciągnięty przed nawias bieżącej działalności. Wspólną wizję obrazuje także precyzyjnie sformułowana misja ujmująca główne wyzwania ważne dla zróżnicowanych interesariuszy (Strategia, 2000).

Zespołowe uczenie się to permanentny dialog na partnerskich zasadach (Senge, 2012). Zespół to z jednej strony kadra UMWM, a z drugiejszerokie grono osób i instytucji zaangażowanych w proces. Analizując przebieg prac, można dostrzec, że samorząd regionalny nie dominował dialogu, zapraszając szerokie grono partnerów i konsultując nie tylko finalny dokument, ale także opracowania częściowe. Dbano o tak ważną przy uczeniu się organizacji informację zwrotną poprzez odnoszenie się do zgłaszanych uwag i podsumowywanie kolejnych etapów pracy. Proces został udokumentowany, co pozwoliło na akumulację wiedzy w organizacji (Nonaka, 1991). Dzięki odpowiedniemu przedstawieniu graficznemu i komunikatywnym materiałom promującym Strategie wykorzystano potencjał wizualizacji jako narzędzia wspomagającego uczenie się.

Mistrzostwo osobiste odnoszone jest do zaangażowania, odpowiedzialności, ciągłego doskonalenia się, budowania samoświadomości i twórczego napięcia pomiędzy wizją i rzeczywistością (Senge, 2012).

3 Formuła unijnych siedmioletnich perspektyw finansowych ma również na celu zorganizowaną refleksję administracji i jej partnerów. 
Próba oceny, czy uczestnikom opisanego procesu przyświecały idee osobistego mistrzostwa, jest trudna. Łatwiej ocenić efekty tych działań. To władze samorządowe i pracownicy UMWM stworzyli atmosferę otwartości, inicjując i koordynując dialog. Działania mogły się skupić wyłącznie na „literze” prawa i osiagnięciu produktu w postaci dokumentu Strategii. Regionalni liderzy (bo tak należy ich nazwać) skoncentrowali się jednak na procesie i „duchu” partnerskiego działania. To pomysły i decyzje konkretnych ludzi przyczyniły się do wdrożenia partycypacyjnej, oddolnej metody budowania Strategii. Senge w swojej teorii podkreśla, że mistrzostwo osobiste jest zaraźliwe (Senge, 2012). Ten mechanizm spowodował, że formuła partnerskiego dialogu została zaszczepiona wśród partnerów samorządu, a także mocno wpłynęła na kulturę organizacyjną UMWM (Księga Jakości, 2013).

Analiza powyższych elementów, zdefiniowanych przez Senge’a jako wyróżniki uczenia się organizacji, potwierdza, że administracja samorządowa skutecznie budowała swoje doświadczenia w procesie uczenia się. Patrząc na efekty tego procesu w postaci realizowanych wyzwań strategicznych, jak przygotowanie kolejnych strategii rozwoju i RPO, również należy potwierdzić, że organizacja posiadała wiedzę, kompetencje i podejście.

\section{Wnioski i rekomendacje}

Strategia Rozwoju Województwa Małopolskiego 2000-2006 stanowiła jedno z najważniejszych doświadczeń na drodze poszukiwania koncepcji i narzędzi wdrażania polityki rozwoju. W chwili jej tworzenia samorząd regionalny stawiał pierwsze kroki, brakowało doświadczeń w zarządzaniu strategicznym i długookresowym planowaniu. Jacek Szlachta, czołowy polski regionalista, dopiero po dekadzie zaobserwował „zasadniczy wzrost umiejętności programowania strategicznego na poziomie regionalnym" (Szlachta, 2011, s. 33). Wiedza i kompetencje wzrastały wraz z uruchomieniem programów przedakcesyjnych, a następnie funduszy strukturalnych, kiedy to nastąpił transfer know-how w dziedzinie programowania, zarządzania strategicznego, monitoringu, oceny (Grosse, 2012). Z czasem rolę instrumentu zarządzania regionami przejęły RPO, które w przeciwieństwie do Strategii były wyposażone w budżety.

Przygotowanie dwóch kolejnych strategii zintegrowano z pracami nad RPO. Poprzedzenie przygotowań RPO szerokim regionalnym dialogiem strukturalizowało cele i ułatwiało ich operacjonalizację (Strategia, 2006; Strategia 2011). Doświadczenia pierwszej Strategii ustaliły swoistą ścieżkę działania i podejście do zarządzania strategicznego. 
Podczas przygotowania RPO 2007-2013 wymogi prawne w zakresie procesu konsultacji były już znacznie szersze (Rozporządzenie, 2005). Władze regionalne ponownie wyszły jednak poza obligatoryjne działania, inicjując szeroki dialog. Współpraca z partnerami samorządowymi, gospodarczymi, sektorem pozarządowym, sektorem nauki, administracją rządową i wspólnotową, stworzenie banku projektów, ekspertyzy, konferencje tematyczne, zespoły zadaniowe i warsztaty w UMWM to tylko część z aktywności podjętych w procesie programowania (ROP 2007-2013).

Teoria uczenia się organizacji, dzięki wyeksponowaniu znaczenia człowieka w tym procesie, ma utylitarny charakter. Stanowi ona jednak ułomne narzędzie do pomiaru uczenia się. Każdy z pięciu elementów trudno sparametryzować poprzez efekty. W przypadku organizacji publicznej (gdzie zyskowność nie jest miernikiem) problem jest spotęgowany. W niniejszym studium przypadku potwierdzono występowanie pozytywnych działań w każdym z badanych obszarów, mając świadomość ich niemierzalności i nieporównywalności. Analiza taka była możliwa tylko dzięki długookresowej obserwacji zarówno badanego procesu, jak i jego odziaływania. Teoria Senge'a jest bez wątpienia dobrym drogowskazem dla organizacji w zakresie tworzenia warunków do uczenia się.

Oceniając proces przygotowania Strategii, wydaje się, że województwo małopolskie osiągnęło pożądane rezultaty. Władze samorządowe poprzez charakter swojego zaangażowania i dobór odpowiednich koncepcji strategicznych przyczynity się do tego. Logika uczenia się Davida Kolba, także w przypadku organizacji, przedkłada nade wszystko doświadczenie (Kolb, 1984). W omawianym przypadku doświadczenie zaowocowało triadą: wiedzy, kompetencji oraz „podejścia” do problemów. Triada ta przez lata stanowiła fundament strategicznego zarządzania regionem i determinowała skuteczność Małopolski w absorpcji środków unijnych. Doświadczenia te zostały dostrzeżone i promowane jako dobre praktyki (Sadura, 2016).

Powyższa analiza dowodzi, że organizacje publiczne mogą się uczyć, i to wspólnie z szerokim gronem partnerów, co dla samorządu powinno stanowić paradygmat działania. W omówionym przedsięwzięciu zarysowały się główne procesy uczenia się: impulsy, refleksja, wiedza i adaptacja (Olejniczak, 2012). Były one możliwe dzięki czynnikom, które je wspierały, m.in. takim jak: myślenie systemowe, kultura pracy zespołowej, zaangażowanie, demokratyczne zarządzanie, dostępność informacji zewnętrznych, poszukiwanie informacji zwrotnych, praktyki kodyfikacji działań i akumulacji wiedzy, otwartość i dialog.

Samorządy mogą kreować takie warunki, nie wystarczą tu narzucone prawem ścieżki postępowania. Kluczowe znaczenia ma „duch”, a nie „litera”. Ważny jest proces, a nie jedynie jego końcowy rezultat. 
Świadomość roli partycypacyjnego dialogu i związanego z nim twórczego fermentu daje szanse na umacnianie znaczenia samorządu w jego konstytucyjnym rozumieniu - jako wspólnoty obywateli.

\section{Bibliografia}

Covey, S.R. (2020). 7 Nawyków skutecznego działania. Warszawa: Rebis.

Ewaluacja ex-ante (1999). Instytut Badań nad Gospodarką Rynkową.

Grosse, T.G. (2012). W objeciach europeizacji, wybrane przyktady z Europy Środkowej i Wschodniej. Warszawa: Instytut Studiów Politycznych PAN.

Harmonogram prac nad strategią (1999). Uchwała Sejmiku Województwa Małopolskiego VII/58/99 z dnia 26 kwietnia 1999 r.

Izdebski, H. i Kulesza, M. (2004). Administracja publiczna. Zagadnienia ogólne. Warszawa: Liber.

Kolb, D. (1984). Experiential Learning. Experience as the Source of Learning and Development. New Jersey: Englewood Cliffs, Prentice-Hall.

Koncepcja Good Governance - refleksje do dyskusji (2008). Warszawa: Ministerstwo Rozwoju Regionalnego.

Kontrakt Wojewódzki dla Województwa Małopolskiego na lata 2001-2002, 19 czerwca $2001 \mathrm{r}$.

Księga jakości (2013). Księga Zintegrowanego Systemu Zarządzania. Kraków: UMWM.

Małopolska Lista Szans (2000). Pozyskano z: https://dziennikpolski24.pl/ malopolska-lista-szans/ar/c3-2093928 (dostęp: 12.08.2021).

Mikuła, J. (2000). Prognoza skutków wptywu na środowisko Strategii Rozwoju Województwa Matopolskiego. Kraków.

Nonaka, I. (1991). The Knowledge-creating Company. Harvard Business Review, 69(6). The best of HBR 2007. https://hbr.org/2007/07/the-knowledge-creating-company

NSRO (2006). Narodowe Strategiczne Ramy Odniesienia 2007-2013. Warszawa: Ministerstwo Rozwoju Regionalnego.

Olejniczak, K. (red.) (2012). Organizacje uczace się. Model dla administracji publicznej. Warszawa: Wydawnictwo Naukowe Scholar.

Ospina, S., Esteve, M. i Lee, S. (2017). Assessing qualitative studies in public administration research. Public Administration Review, 78(4). DOI: 10.1111/puar.12837.

Raport z monitoringu Strategii Rozwoju Województwa Małopolskiego za lata 2000-2003 (2003). Kraków: UMWM.

Raport z realizacji Strategii Rozwoju Województwa Małopolskiego na lata 2000-2006 (2004). Kraków: UMWM. 
Raporty Województwo Małopolskie (2000-2006). Pozyskano z: https://www. malopolska.pl/biznes/rozwoj-regionalny/rozwoj-wojewodztwa/raport-o-stanie-wojewodztwa-1 (dostęp: 12.08.2021).

Rozporządzenie Prezesa Rady Ministrów z dnia 13 stycznia 2005 r. w sprawie trybu i terminów konsultacji, współdziałania i współpracy przy opracowywaniu Narodowego Planu Rozwoju, programów operacyjnych i strategii wykorzystania Funduszu Spójności.

Sadura, P. (2016). Konsultacje spoteczne na poziomie wojewódzkim. Omówienie przypadków dobrych praktyk $i$ rekomendacje, Federacja Mazowia. Pozyskano z: https://poledialogu.org.pl/wp-content/uploads/2016/04/ Sadura_konsultacje_spoleczne_na_poziomie_wojewodzkim_mazowia. pdf(dostęp: 11.09.2021).

Senge, P.M. (2012). Piata dyscyplina. Teoria i praktyka organizacji uczacych się. Warszawa: Oficyna Wolters Kluwer Business.

Sprawozdanie końcowe z realizacji Narodowego Planu Rozwoju na lata 2004-2006 (2013). Warszawa: Ministerstwo Rozwoju Regionalnego.

Strategia Rozwoju Województwa Małopolskiego 2000-2006 (2000). Kraków: UMWM.

Strategia Rozwoju Województwa Małopolskiego 2007-2013 (2006). Kraków: UMWM.

Strategia Rozwoju Województwa Małopolskiego 2011-2020 (2011). Kraków: UMWM.

Szlachta, J. (2011). Strategiczne programowanie rozwoju regionalnego, w kierunku krajowego systemu myśli strategicznej w sferze polityki regionalnej. W M. Kolczyński i P. Żuber (red.), Nowy paradygmat rozwoju-najnowsze trendy i perspektywy polityki regionalnej. Warszawa: Ministerstwo Rozwoju Regionalnego.

Ustawa o dostępie do informacji publicznej z dnia 6 września $2001 \mathrm{r}$.

Ustawa o samorządzie województwa z dnia 5 czerwca 1998 r.

Wojewódzki Program Operacyjny Rozwoju Regionalnego Małopolski na lata 2001-2002 (2000). Kraków: UMWM.

Yin, R.K. (2015). Studium przypadku w badaniach naukowych. Projektowanie $i$ metody. Kraków: Wydawnictwo Uniwersytetu Jagiellońskiego.

Założenia do Strategii Rozwoju Województwa (1999). Uchwała Sejmiku Województwa Małopolskiego XI/102/99 z dnia 30 sierpnia 1999 r.

Zawicki, M. (2010). Deficyty współzarządzania publicznego w Unii Europejskiej. W A. Bosiacki, H. Izdebski, A. Nelicki i I. Zachariasz, Nowe zarzadzanie publiczne i public governance $w$ Polsce i $w$ Europie. Warszawa: Liber.

Hubert Guz - doktor ekonomii (zarządzanie), adiunkt w Katedrze Polityki Publicznej i Administracji Akademii Ignatianum w Krakowie, przez 20 lat związany z samorządem regionalnym, do 2019 r. dyrektor Departamentu Funduszy Europejskich w Urzędzie Marszałkowskim 
Województwa Małopolskiego; doświadczenie w zarządzaniu programami, projektami i dużymi zespołami, zainteresowania: organizacyjne uczenie się, samorząd, polityka spójności UE.

Konrad Oświecimski - adiunkt w Instytucie Nauk o Polityce i Administracji Akademii Ignatianum w Krakowie. Jego zainteresowania badawcze oraz dokonania publikacyjne oscylują wokół wpływu politycznego, lobbingu, a także kampanii wyborczych i politycznych. 